\title{
The precarious state of the art: Writing the Global South and critical cosmopolitanism in the works of J.M. Coetzee and Roberto Bolaño
}

porque todo es sur en el mundo, las estrellas que no vemos y las que vemos, fascinación y cerrazón, dalia y más dalia de tinta

Gonzalo Rojas, "Para órgano"

\section{Re-mapping World Literature: opportunities and prospects of readings of the Global South}

In 1952, Erich Auerbach, facing the devaluation of "traditional divisions of the material, chronological, geographical or typological” (1969: 12), harbored radical doubts regarding the possibilities presented by speaking about World Literature in a Goethean sense. This does not appear to have impeded the (recent) success of this concept within literary studies of the past 20 years. Without delving into a detailed reappraisal of this constantly expanding debate, it seems nonetheless important, given the current contagiousness of the concept of the Global South, to at least locate its relationship to, and possible value for the treatment of questions pertaining to World Literature. Both theoretical and analytical discussions of the notion of World Literature differ, at a basic level, with regard to the various ways in which we respond to two fundamental questions:

1. What ideas about the world and about literature does each analytical perspective articulate through the compound noun, World Literature?

2. How does each approach determine the possibility of an adequate ability to describe World Literature, in the sense of a literary global history?

In response to the first question, debates focus in particular on the status of literature itself in the medium of the global. One side privileges literature's ability to function as a world-making force with its possibility for creating alter-worlds 
(Cheah 2014: 2), thereby putting front and center the analysis of the literary text. The other side's interest in knowledge springs from the assumption that "there is no unmediated relationship between the practice of writing and the printed, commodified, and possibly consecrated text” (Helgesson 2015: 24), which is why, consequently, this sort of work concentrates on extra-literary mechanisms of global book markets ${ }^{1}$. If these different approaches can be reconciled with relative ease, in the sense of Damrosch's claim that "systemic approaches need to be counterbalanced with close attention to particular languages, specific texts" (2003: 26), this makes the second question all the more difficult to answer, inquiring as it does into the problem of what kind of world we are speaking of when we invoke World Literature, and how we can conceive of this world in its spatial and temporal axes. Pascale Casanova's La république mondiale des lettres continues to offer what is without a doubt the clearest illustration of this problem. From her Euro or Francocentric perspective, world is only conceivable in dependency upon one geographical and temporal center - Paris in the age of modernity - which offers the opportunity to create a master narrative that would render manageable a body of literatures of the world that is otherwise simply impossible to imagine in its mass and diversity ${ }^{2}$. The problem with such attempts at world-literary historiography lies in the fact that they are always subject to ideological distortions and as such cannot fulfill descriptive claims made on global-historical configurations of literature. Jerome McGann formulated this in a pointed way in his critique of Casanova:

The factive inadequacy of Casanova's account does not measure a failure of scholarship, it marks her ideological purpose. Like the artwork that interests her, Casanova's discussion "escape[s] the ordinary laws of history." It isn't a history at all, it is a theory, and "Paris" for her is a myth - "a modern myth created by literature". [...] But if Paris is a myth escaping the ordinary laws of history, the myth is itself a historical formation and is important as such. It is clearly important if people put faith in the myth - or if they don't. (2008: 651)

The idea of a world or World Literature, as treated in works like Casanova's, bears the inherent seed of a problem that Dipesh Chakrabarty, in his reflections on global history, exposes whenever he describes the understanding of globality in historicism shaped by European thought: "Historicism is what made modernity

1 See also the other contributions in Helgesson/Vermeulen (2015), or the study by Marling (2016) about gatekeepers, a work exemplary for the influence of specific actors within the global literary field.

2 Franco Moretti's notion of distant reading represents a completely different, yet no less problematic, attempt to tame this body of material; I will not discuss this in detail here. See the texts in Moretti (2013), as well as my extensive critique of Moretti and Casanova's Hegelian historiography in Loy (2017a). 
or capitalism look not simply global but rather as something that became global over time, by originating in one place (Europe) and then spreading outside it [...] Historicism thus posited historical time as a measure of the cultural distance [...] that was assumed to exist between the West and the non-West” (2008: 7). Just as Chakrabarty has demonstrated for concepts such as Capitalism, Modernity or Enlightenment, World Literature can be defined as a phenomenon that "[is] explained mainly with respect to 'events' within the geographical confines of Europe [...]. The inhabitants of the colonies, on the other hand, were assigned a place 'elsewhere' in the 'first in Europe and then elsewhere' structure of time" (2008: 7-8). It seems to me that it is precisely this problem of "banishing" nonWestern texts or textual histories to some "imaginary waiting room of history" (2008: 8), and the therefore consistently insufficient semantic charge of the term world within present ideas of World Literature that gives rise to the significance and possibilities of ideas such as the Global South. With its focus on "the tensions between ordering and disordering implicit" in the Global South, it "might provide a useful heuristic for those engaged in a wide range of intellectual, aesthetic, and political work" (Levander/Mignolo 2011: 1). The fact that questions emerging from the vantage point of South-South relations "call global designs into question and open up the possibility of networking among local histories" (Levander/Mignolo 2011: 10) seems to facilitate an opportunity to complicate and critique a simplistic notion of the world à la Casanova. Such questions illuminate, in a specific way, a postulation that Damrosch has already formulated (also not unproblematically), namely that every work of world literature always has "a perspective from somewhere" (2003: 27). A re-mapping of the contemporary cartographies of World Literature rooted in Western modernity from the perspective of the Global South would therefore be appropriate to open up a nuanced idea of literary globality without negating the central importance and influential power of Occidental concepts such as Modernity or even World Literature, because, as Chakrabarty has convincingly argued, it is "impossible to think of [them] anywhere in the world without evoking certain categories and concepts, the genealogies of which go deep into the intellectual and even theological traditions of Europe" (2008: 4). From the perspective of the Global South, World Literature would therefore be conceived of as an "expansion of the world" and a "provincialization" of the West, in the context of envisioning the fact that "universalistic thought was always and already modified by particular histories, whether or not we could excavate such pasts fully" (2008: xiv) ${ }^{3}$. The concomitant perspective is

3 For Latin American literatures, the studies by Mariano Siskind (2014) and Héctor Hoyos (2015) come closest to realizing this postulation. 
therefore "not [directed] against the idea of universals as such but emphasize[s] that the universal was [and is] a highly unstable figure" (2008: xiii).

With regard to the question of literature - as the following analysis of works by J.M. Coetzee and Roberto Bolaño is meant to document - such a critical perspective from the view of two authors, who write and wrote from a typical position between, or swinging to and from, the Global South (South Africa and Mexico/Chile) and the Global North (Australia and Spain), always implies the problematization of a fundamentally affirmative stance towards literature or World Literature as a medium of historical affirmation and cosmopolitan positioning, which suits many discourses in the current debates ${ }^{4}$.

\section{The humanities in neoliberal times, or the crisis of the cosmopolitan imagination}

If we read the Global South as "the geopolitical concept replacing 'Third World' after the collapse of the Soviet Union” (Levander/Mignolo 2011: 3), then we can situate the works of J.M. Coetzee, born in 1940 in Cape Town, and Roberto Bolaño, born in 1953 in Santiago de Chile, against the backdrop of the watershed year of 1989 and its accompanying hopes and crises. The following analysis will focus on Coetzee's Disgrace (1999) and Elizabeth Costello (first published in 2003), and on Bolaño's closely intertwined and posthumously published novels, 2666 (2004) and Woes of the True Policeman (first published in 2011 as Los sinsabores del verdadero policía). The protagonists of all four texts, which are partially autobiographical in nature ${ }^{5}$, are connected by the fact that all of them are philologists ${ }^{6}$ (David Lurie in Disgrace, Blanche Costello in Elizabeth Costello, and Espinoza, Pelletier, Morini, Norton and Amalfitano in Bolaño's novels) or a philologically adept writer (Elizabeth Costello). As such, these characters reveal how these texts confront meta-questions of literature and processes of reading and interpretation. We can locate the presentation of

\footnotetext{
4 Regarding one critique in this context, see Apter (2013), although her comments focus more strongly on the problem of translatability.

5 This study does not further explore the important question of how authors are staged and how this effects global reception. On Coetzee, see Helgesson (2015); on Bolaño, see Birns (2015). 6 I'm aware of the somewhat uncommon use of the designation "philologist" in English, however I use it here to refer to a specific and historic idea of literary scholarship, as discussed for example by Hans Ulrich Gumbrecht in his book The Powers of Philology.
} 
all of these philological protagonists and their academic contexts within the radical global and neoliberal reorganization of universities and other educational institutions that stand at the root of the "world-wide crisis in education" (Nussbaum 2010: 2), within which the humanities in particular are threatened by educational policy focused solely on utilitarian premises or, as the text "The Humanities in Africa” in Elizabeth Costello puts it,

The studia humanitatis have taken a long time to die, but now, at the end of the second millennium of our era, they are truly on their deathbed. All the more bitter should be that death, I would say, since it has been brought about by the monster enthroned by those very studies as animating principle of the universe: reason, mechanical reason. (Coetzee 2004: 123)

In both Coetzee and Bolaño's novels, the humanities in general, and philology in particular, seem to be disciplines stripped of all transcendence and potential efficacy, populated by figures degraded from literature professors to "professors of communications"; Lurie describes them as "clerks in a post-religious age" (Coetzee 1999: 3). The university and its students are guilty of corruption, squalidness and ignorance. As Bolaño writes, "[t]he university is rotten" (Bolaño 2012: 17) ${ }^{7}$, and Lurie notes, "He has long ceased to be surprised at the range of ignorance of his students. Post-Christian, posthistorical, postliterate, they might as well have been hatched from eggs yesterday" (Coetzee 1999: 32). The Chilean philologist Óscar Amalfitano, who says that it seems "as if in these times of crisis literature professors weren't needed anywhere” (Bolaño 2012: 24$)^{8}$, thereby corresponds with a general theoretical ennui among the representatives of a discipline that are only all too aware of their devaluation in the age of neoliberalism and who yearn to escape from their business of interpretation: "The truth is, he is tired of criticism, tired of prose measured by the yard. What he wants to write is music: Byron in Italy, a meditation on love between the sexes in the form of a chamber opera" (Coetzee 1999: 4) ${ }^{9}$. All of the novels exhibit to a similar degree the affective inadequacy of philology as textual science, which Bolaño presents, with a certain exaggeration, as a kind of pretext for the satisfaction of all-too-human desires. For example, Bolaño

7 "La universidad está podrida" (Bolaño 2011: 39).

8 "[C]omo si en estos tiempos de crisis en ningún lugar hicieran falta profesores de literatura" (Bolaño 2011: 46).

9 The ostensible motivation of these philologists bears an astonishing resemblance to the longing for "experiences of presence" on this side of a rationally founded hermeneutics, so prominently articulated by Hans Ulrich Gumbrecht in Production of Presence (2003). See also Loy (2017b) for a critique of this concept. 
writes the following about the French literature scholar Jean-Claude Pelletier and his career at the beginning of 2666 :

\begin{abstract}
He saw himself, as we've said, ascetic and hunched over his German dictionaries in the weak light of a single bulb, thin and dogged, as if he were pure will made flesh, bone, and music without an ounce of fat, fanatical and bent on success. A rather ordinary picture of a student in the capital, but it worked on him like a drug, a drug that brought him to tears, a drug that (as one sentimental Dutch poet of the nineteenth century had it) opened the floodgates of emotion, as well as the floodgates of something that at first blush resembled self-pity but wasn't (what was it, then? rage? very likely), and made him turn over and over in his mind, not in words, but in painful images, the period of his youthful apprenticeship. (Bolaño 2008: 5) ${ }^{10}$
\end{abstract}

As the boredom of the philologists increases throughout the course of the novels, they engage in amorous escapades that end up functioning as another problematization of their ostensibly humanistic convictions and of literature itself: David Lurie has an affair with a young student named Melanie, which ends up costing him his job at a university in Cape Town; similar events unfold for Óscar Amalfitano, who is at first employed at the University of Barcelona and then, after many years of being a widower, discovers his homosexuality and is also dismissed after having an affair with a student; and 2666 features a ménage $\grave{a}$ trois between the two critics Pelletier and Espinoza and their young colleague Liz Norton, which triggers a series of problematic events in the course of the novel. What is interesting in this context, however, are the affective-political implications of presenting the protagonists' academic worlds as hypocritical and, as the title of Coetzee's novel indicates, merciless institutions. While Amalfitano's colleagues merely tell him, "You should have been more careful choosing your friends" (Bolaño 2012: 17) ${ }^{11}$, Disgrace explores Lurie's predicament in far more detail. The novel grants a broad forum to the intense disciplinary procedures brought against Lurie, focusing - in a scarcely concealed allusion to the trial at

10 "Se vio, como queda dicho, a sí mismo, ascético e inclinado sobre sus diccionarios alemanes, iluminado por una débil bombilla, flaco y recalcitrante, como si todo él fuera voluntad hecha carne, huesos y músculos, nada de grasa, fanático y decidido a llegar a buen puerto, en fin, una imagen bastante normal de estudiante en la capital pero que obró en él como una droga, una droga que lo hizo llorar, una droga que abrió, como dijo un cursi poeta holandés del siglo XIX, las esclusas de la emoción y de algo que a primera vista parecía autoconmiseración pero que no lo era (¿qué era, entonces?, ¿rabia?, probablemente), y que lo llevó a pensar y a repensar, pero no con palabras sino con imágenes dolientes, su período de aprendizaje juvenil” (Bolaño 2004: 17).

11 "Debiste ser más prudente a la hora de elegir a tus amigos" (Bolaño 2011: 38). 
the end of Albert Camus' L'Étranger ${ }^{12}$ - on the central theme of bigotry in a postreligious world that has lost its capacity to grant mercy, even though it remains a world that vehemently calls for certain basic affective forms of atonement. Lurie clearly labels this conflict when he refuses to deliver a performance of regret about his objective violation of the institutional rules: "Before that secular tribunal I pleaded guilty, a secular plea. That plea should suffice. Repentance is neither here nor there. Repentance belongs to another world, to another universe of discourse" (Coetzee 1999: 58). At the same time, the protagonists in the other novels are not staged at all as innocents whose fall from grace should be understood as a consequence of a pitiless zeitgeist. Lurie's ex-wife, however, identifies this fact in a relatively clear way when she says, "Don't expect sympathy from me, David, and don't expect sympathy from anyone else either. No sympathy, no mercy, not in this day and age. Everyone's hand will be against you, and why not?" (1999: 44).

At the same time, however - and this is crucial to the problematization of the humanities and literature in both Coetzee and Bolaño - all of these texts address the question of how literature and affect are related, and they also thematize the presumably positive connections that ostensibly exist between both specifically defined views of literature and interpretation. This pertains in particular to the influential idea that literature holds a specific power for inculcating certain empathic capabilities and - here the global dimension of the novels finally comes into play - the facilitation of a cosmopolitan worldview. In the recent past, this connection between reading fictions, education in empathy, and cosmopolitanism was most prominently articulated by authors such as Martha Nussbaum and Kwame Anthony Appia. For example when Nussbaum in her widely discussed book Cultivating Humanity, postulates: "[N]arrative imagination is an essential preparation for moral interaction. Habits of empathy and conjecture conduce a certain type of citizenship and a certain form of community: one that cultivates

12 This intertextual line of reference, which is extended in the novel to other places to Gustav Flaubert, is an indication of the fact that Coetzee's politics of affect are in no way an ostensibly new form of the novel, as Peter Vermeulen for example has argued, and that Coetzee's work does not spell the "end of the novel" because they supposedly do not fulfill the genre's traditional affective objectives (compare this with Vermeulen's central thesis, according to which "over a century of theoretical reflection on the novel has understood it as a cultural form that has inaugurated and sustained modern forms of individuality and community; it has done so, moreover, by mobilizing two vital kinds of emotive engagement with the world: desire and empathy" (Vermeulen 2014: 50-51)). Instead, Coetzee intentionally presents a newly defined form of the affective negotiation of emotional coldness, as it was constitutive for a certain line of modernity and whose founder was Gustav Flaubert. See also von Koppenfels (2007). 
a sympathetic responsiveness to another's needs" (1997: 90). According to Nussbaum's argument, which follows Diogenes, the reading of fictional texts - and the study of "non-western cultures" in particular - and the associated capacity for putting oneself in another's position in a gesture of empathy, enables literature to fulfill an essential task in the affective education of mankind and his transformation into a cosmopolitan citizen of the world: "When we see in how many different ways people can organize their lives we will recognize [...] what is deep and what is shallow in our own ways, and will consider that 'the only real community is one that embraces the entire world'” $(1997: 58)^{13}$. In fact, however, the view articulated here by Nussbaum ${ }^{14}$ is influential within a Western tradition and constitutes a certain affirmative propagation of the cosmopolitan potential of (world) literature. This notion has come under increasing pressure in contemporary research whenever authors such as Suzanne Keen in her study Empathy and the Novel have asserted that

$[\mathrm{N}] \mathrm{o}$ evidence emerges [...] that would support a judgment about the importance or insignificance of novel reading in cultivating the sympathetic imaginations [...] this lack of information does not preclude influence through fiction reading, to be sure, but it does warrant caution when making claims about the formation of these particular good world citizens. $(2007: 23)^{15}$

In fact, Keen emphasizes the fundamental ambivalence of narratives when she discusses, in reference to the example of the Holocaust that she repeatedly raises, the degree to which the narrative of the inhumane, situated for example in language about the racial superiority of Aryans in Nazi ideology, must be discussed in connection with the power of fictions: "The content of stories is not a neutral matter. If narrative fiction has the capacity to alter readers' characters for the good, it may also possess darker powers" (2007: 25). In their novels under discussion here, Roberto Bolaño and J.M. Coetzee seem to call into question this idea by critically examining the Western notion that literature is a cosmopolitan power that can improve the world; in Elizabeth Costello's thoughts about the connection between literature and evil, for example, there is the explicit statement that, "Specifically, she is no longer sure that people are always improved by what they read. Furthermore, she is not sure that writers who venture into the darker territories of the soul always return unscathed" (2004: 160). As a matter of fact, both authors deal

13 See also the similar, if more differentiated, comments in Appiah (2001).

14 Ette (2016) also presents a similarly empathic vision of literatures of the world as a reservoir of knowledge relevant to the survival of humanity.

15 Paul Bloom has also voiced similar concerns about the ubiquitous apotheosis of sympathy and empathy beyond the specific medium of literature in his latest book, Against Empathy. 
with this problem through the philological protagonists in their novels, namely the problem as to the extent to which, following Nussbaum's argument, specialists in questions of empathy and a cosmopolitan ethos fail on the practical application of these ethical convictions, or the degree to which fiction and their humanistic knowledge enable them, in certain situations, to develop adequate possibilities for idealizing ethically problematic actions. This aspect becomes clear after Lurie's first sexual encounter with his student, Melanie, when Lurie comments as follows on the intentionally ambivalent scene after the end of the act: "Her tights and panties lie in a tangle on the floor; his trousers are around his ankles. After the storm, he thinks: straight out of George Grosz" (Coetzee 1999: 19). Lurie's humanistic education here becomes the prerequisite for the romanticization of an ethically problematic deed, one that surfaces for just a moment in his conscience in all of its objective reprehensibility: "A child! [...] No more than a child! What am I doing?” (1999: 20). This problem is addressed in a similar explicit way at the end of the novel when Lurie attends a theater performance in which Melanie is on stage. During the performance, Lurie reflects upon all of the women in his life and states indiscriminately, "by each of them he was enriched” (1999: 192). The reader first sees how the behavior of the condemned and ostracized Lurie affects his environment when a friend of Melanie's points out the inappropriateness of the sacked philologist's presence at his “victim's” performance:

“Only doing you a favour, prof. Didn’t you learn your lesson?”

“What was my lesson?"

"Stay with your own kind."

Your own kind: who is this boy to tell him who his kind are? What does he know of the force that drives the utmost strangers into each other's arms, making them kin, kind, beyond all prudence? Omnis gens quaecumque se in se perficere vult. The seed of generation, driven to perfect itself, driving deep into the woman's body, driving to bring the future into being. Drive, driven. (1999: 194)

On the other hand, Lurie's attempt to conceal his desires in the register of abstraction or his education reaches its pinnacle at the end of the chapter when, after the incident, he picks up a prostitute off the street and describes his instrumental relationship with her in a way devoid of idealism: "The girl is drunk or perhaps on drugs: he can get nothing coherent out of her. Nonetheless, she does her work on him as well as he could expect" (1999: 194). At the same time, the novel repeatedly instantiates the possible limits of the empathic imagination, for example when the neighbor of Lurie's daughter Lucy accuses him after her rape of a sheer inability to put himself in her shoes, to which Lurie responds, “You don't understand, you weren't there, says Bev Shaw. Well, she is mistaken. 
Lucy's intuition is right after all: he does understand; he can, if he concentrates, if he loses himself, be there, be the men, inhabit them, fill them with the ghost of himself. The question is, does he have it in him to be the woman?" (1999: 160). Katherine Hallemeier has shown how Coetzee's novel Boyhood articulates a criticism of the limits of the cosmopolitan imagination that authors such as Nussbaum promote, which tends in its universalizing impetus (and against its actual objective) towards a levelling of differences and power structures. We see this in Disgrace in Lurie's relationship to his (black) female student. According to Hallemeier, "Cosmopolitanism comes to stand as a theoretical term that gestures towards valuing differences of class, race, and gender. This gesture, however, subsumes material differences under a common human condition, even as the attribution of cosmopolitan feeling to subordinated groups arguably reinforces those groups' subordination” (2013b: 95).

Roberto Bolaño's 2666 also permits a similar treatment of this topic, as is evident in two scenes from the first of four parts of the novel, each dedicated to a scholar of literature. In the first scene, Jean-Claude Pelletier and his Spanish colleague Manuel Espinoza are visiting Liz Norton in London; both of them are pursuing her romantically. They surprise Norton in her apartment as she is speaking with her supposed ex-boyfriend, and the sexual and affective background of the following scene carries over on the same evening into a taxi ride through the city:

And when Norton told him he was lost and said which streets he should take to find his way, the driver fell silent again, with no more murmurings in his incomprehensible tongue, until he confessed that London was such a labyrinth, he really had lost his bearings. Which led Espinoza to remark that he'd be damned if the cabbie hadn't just quoted Borges, who once said London was like a labyrinth - unintentionally, of course. To which Norton replied that Dickens and Stevenson had used the same trope long before Borges in their descriptions of London. This seemed to set the driver off, for he burst out that as a Pakistani he might not know this Borges, and he might not have read the famous Dickens and Stevenson either, and he might not even know London and its streets as well as he should, that's why he'd said they were like a labyrinth, but he knew very well what decency and dignity were, and by what he had heard, the woman here present, in other words Norton, was lacking in decency and dignity, and in his country there was a word for what she was, the same word they had for it in London as it happened, and the word was bitch or slut or pig, and the gentlemen here present, gentlemen who, to judge by their accents, weren’t English, also had a name in his country and that name was pimp or hustler or whoremonger. (Bolaño 2008: 73) ${ }^{16}$

16 "Y cuando Norton le dijo que se había perdido y le indicó qué calles debía tomar para enderezar el rumbo el taxista permaneció, otra vez, en silencio, sin más murmullos en su lengua incomprensible, para luego reconocer que, en efecto, el laberinto que era Londres había conseguido desorientarlo. Algo que llevó a Espinoza a decir que el taxista, sin proponérselo, coño, 
The violent reaction from the literature professors to this criticism of their amorous threesome comes right away, whereby the subsequent physical abuse of the taxi driver is accompanied by a series of curses in which the academics express their allegedly cosmopolitan positions against someone they consider to be a reactionary Pakistani: "[S]hove Islam up your ass, which is where it belongs, this one is for Salman Rushdie (an author neither of them happened to think was much good but whose mention seemed pertinent), this one is for the feminists of Paris, [...] this one is for the ghost of Valerie Solanas, you son of a bitch" (Bolaño 2008: 74 ${ }^{17}$. Much like the actions of Coetzee's protagonist, Lurie, the implications of this scene posit a radical doubt of the connection between cultural and cosmopolitan education and the ethical and moral actions that issue from it. The deeper implications of this critique of cosmopolitanism become obvious when Pelletier and Espinoza turn to other erotic adventures after the failure of their liaison with Norton. Pelletier starts up an affair with a prostitute named Vanessa, who is described in the novel as follows:

According to her, her husband was a saint. He had some flaws - for example he was an Arab, Moroccan to be precise, plus he was lazy - but overall, according to Vanessa, he was a good person, who almost never got angry about anything, and when he did, he wasn't violent or cruel like other men but instead melancholy, sad, filled with sorrow in the face of a world that suddenly struck him as overwhelming and incomprehensible. When Pelletier asked whether the Arab knew she worked as a prostitute, Vanessa said he did, that he knew but didn't care, because he believed in the freedom of individuals.

claro, había citado a Borges, que una vez comparó Londres con un laberinto. A lo que Norton replicó que mucho antes que Borges Dickens y Stevenson se habían referido a Londres utilizando ese tropo. Cosa que, por lo visto, el taxista no estaba dispuesto a tolerar, pues acto seguido dijo que él, un paquistaní, podía no conocer a ese mentado Borges, y que también podía no haber leído nunca a esos mentados señores Dickens y Stevenson, y que incluso tal vez aún no conocía lo suficientemente bien Londres y sus calles y que por esa razón la había comparado con un laberinto, pero que, por contra, sabía muy bien lo que era la decencia y la dignidad y que, por lo que había escuchado, la mujer aquí presente, es decir Norton, carecía de decencia y de dignidad, y que en su país eso tenía un nombre, el mismo que se le daba en Londres, qué casualidad, y que ese nombre era el de puta, aunque también era lícito utilizar el nombre de perra o zorra o cerda, y que los señores aquí presentes, señores que no eran ingleses a juzgar por su acento, también tenían un nombre en su país y ese nombre era el de chulos o macarras o macrós o cafiches" (Bolaño 2004: 102).

17 “[M]étete el islam por el culo, allí es donde debe estar, esta patada es por Salman Rushdie (un autor que ambos, por otra parte, consideraban más bien malo, pero cuya mención les pareció pertinente), esta patada es de parte de las feministas de París [...], esta patada es de parte del fantasma de Valerie Solanas, hijo de mala madre” (Bolaño 2004: 103). 
“Then he’s your pimp”, said Pelletier. (Bolaño 2008: 81) ${ }^{18}$

In this scene, Bolaño demonstrates the distorted perception of reality of his literature professors and the arbitrariness with which these allegedly cosmopolitan individuals pass value judgments. While they become violent in response to the Pakistani's insult of them as "pimps" and accuse him of a lack of liberality, these categories do not apply to Vanessa and her Moroccan husband, whom Pelletier describes as her "pimp" with an instinctive naturalness, even though it is obvious that this married couple have cultivated a libertarian model of a relationship with the key difference that Vanessa, due to her material situation, is forced to demand money for sexual contacts with other men. Instead of reflecting on the concrete conditions of specific actions - Vanessa sleeps with other men due to her lack of money, just as Melanie does not know how to ward off her professor's advances in Disgrace because of their asymmetrical power relationship Pelletier also prefers a flight into abstraction whenever he tells Espinoza about his beloved by alluding to the "noble savage": "Vanessa was perfectly suited to live in the Middle Ages, emotionally as well as physically. For her, the concept of 'modern life' was meaningless. She had much more faith in what she could see than in the media" (Bolaño 2008: 83) ${ }^{19}$. This thematic complex becomes even more exaggerated in the episode with Espinoza, who during his stay with Pelletier and Norton in Santa Teresa - the city in which hundreds of murders of women are described in the novel's fourth chapter - initiates an affair at a market with a young carpet seller named Rebeca ${ }^{20}$. This relationship is also defined by the

18 "Según ella, su marido era un santo. Tenía algunos defectos, por ejemplo era árabe, marroquí concretamente, y también era flojo, pero en líneas generales, según Vanessa, se trataba de un tipo con buen rollo, que casi nunca se enojaba por nada y que cuando lo hacía, al contrario que el resto de los hombres, no se ponía violento ni mal educado sino melancólico, triste, apesadumbrado ante un mundo que de pronto se le revelaba demasiado grande e incomprensible. Cuando Pelletier le preguntó si el árabe sabía que hacía de puta, Vanessa dijo que sí, que lo sabía pero que no le importaba pues creía en la libertad de los individuos.

-Entonces es tu chulo -le dijo Pelletier” (Bolaño 2004: 111-112).

19 "Vanessa estaba perfectamente preparada, tanto anímica como físicamente, para vivir en la Edad Media. Para ella el concepto «vida moderna» no tenía sentido. Confiaba mucho más en lo que veía que en los medios de comunicación” (Bolaño 2004: 114). His colleague Espinoza makes this connection explicit when he dismisses Pelletier's observations with the remark, "Whores are there to be fucked [...] not psychoanalyzed” (Bolaño 2008: 84). (“-A las putas [...] hay que follárselas, no servirles de psicoanalista” (Bolaño 2004: 115)).

20 As is typical for Bolaño, this episode is also based on an intertextual allusion to the Rebeca motif, as it appears in Daphne du Maurier's novel or Alfred Hitchcock's film, and here in Espinoza's attempt to comfort himself about the "loss" of Liz Norton. 
concrete material disparities between the Spanish professor of literature and the Mexican merchant; first, Espinoza buys an entire series of carpets in order, as the novel puts it, to "make up for it buying what he imagined the others would have bought" (Bolaño 2008: 141) ${ }^{21}$. Bolaño uses the notion that anything can be bought, which surfaces multiple times in the novel ${ }^{22}$, to expound upon the fact that this implies the total availability of bodies, and of life itself, as is expressed in Santa Teresa, a fictionalized Ciudad Juárez ${ }^{23}$, a place where the mass killing of women reifies in a radical way what Zygmunt Bauman has called "wasted life" (see Bauman 2004) ${ }^{24}$. Espinoza, a professor of literature, is placed explicitly in the proximity of a murderer of women and the deadly idea of total power to dispose over the lives of others when a subsequent description presents how he appropriates Rebeca, through the power of his material opportunities, as a kind of sex toy: "In the afternoon he went shopping. He went into a lingerie shop and a women's clothing shop and a shoe shop. That night he brought Rebeca to the hotel and after they had showered together he dressed her in a thong and garters and black tights and a black teddy and black spike-heeled shoes and fucked her until she was no more than a tremor in his arms" (Bolaño 2008: 153-154) ${ }^{25}$.

The crucial implications of this presentation of a world in which the biopolitical violence of capitalist modernity and the Western tradition of humanism are interconnected is founded in the aforementioned problem of the imagination as a means for the idealization or abstraction of a reality experienced as banal; this was formative for the aesthetics of modernity and in 2666, verses of Baudelaire's poem “Le Voyage” are superimposed in an intertextual manner on the novel's

21 "[S]ubsanar el mal comprando él lo que supuso que hubieran comprado los otros“ (Bolaño 2004: 186). (We should note here that the English translation cannot maintain the interpretive possibilities of the Spanish original and its usage of "the remediation of evil").

22 See for example the episode with the horse race between a German and an Argentine youth at the beginning of the novel (Bolaño 2004: 36).

23 See also Bolaño's comparison of Ciudad Juárez with hell in an interview, describing the city as "our curse and our mirror", "the uneasy mirror of our frustration and of our disgraceful interpretations of freedom and of our desires" (Braithwaite 2006: 69)

24 Bolaño describes the continuity of this mechanism of exclusion in modernity between those who are equipped with civil rights and those who, according to Agamben, live a life described explicitly in 2666 as "naked"; see for example the passage in Bolaño 2004: 338-339.

25 "Por la tarde salió a hacer compras. Entró en una lencería y en una tienda de ropa de mujer y en una zapatería. Esa noche se llevó a Rebeca al hotel y después de ducharse juntos la vistió con un tanga y ligueros y medias negras y un body negro y zapatos de tacón de aguja de color negro y la folló hasta que ella no fue más que un temblor entre sus brazos” (Bolaño 2004: 201). 
credo: "An oasis of horror in a desert of boredom"26. Baudelaire's poem describes the quasi-anthropological condition of modern man in the sense of a transcendence that can never be attained, one which is only momentary and transient and can be had in the form of ecstatic experiences. As Markus Messling has impressively shown, Bolaño's 2666 calls up a complex of problems through this reference, which has lost none of its currency at the beginning of the twenty-first century; indeed, this problem has become more radical, denying even the hope of salvation through art, as a further rejection of the optimistic idea of a cosmopolitan and ethically grounded form of the aesthetic. “In Bolaño's 2666, this world no longer produces order and redemption; the novel transforms the classical foundation of literary 'modernity' to the primal scene of and anthropological affinity between aesthetics and violence" (Messling 2014: 205) ${ }^{27}$. What both Coetzee and Bolaño thereby indicate in principle can be described as a fundamental skepticism against the ideas of (artistic) cosmopolitanism, which are always bound to a utopian ideal. As Pheng Cheah has shown elsewhere, this notion is always exposed to contamination by global inequalities and local power structures because "neither human rights nor cosmopolitan solidarities can escape from being entangled within the field of instrumentality. They are pulled back into and find themselves mired within the imperatives and techniques of globalization at many different levels" (2006: 8). The following discussion explores in greater detail how this aspect is dealt with in Coetzee and Bolaño's novels in the context of those precarious territories of the Global South, leading at the same time to historical and philosophical implications.

26 Coetzee refers back to this Baudelairean problematic of spleen and idéal, of reality and ideality, at the beginning of Disgrace with an episode from Wordsworth's Alpine excursion in The Prelude, when Lurie reflects, as he looks at Melanie sitting before him: “The clouds cleared', says Wordsworth, the peak was unveiled and we grieved to see it. A strange response, for a traveler to the Alps. Why grieve? Because, he says, a soulless image, a mere image on the retina, has encroached upon what has hitherto been a living thought [...] we cannot live our daily lives in a realm of pure ideas cocooned from sense-experience. The question is not, How can we keep the imagination pure, protected from the onslaughts of reality? The question has to be, Can we find a way for the two to coexist?" (1999: 21-22). See also Vermeulen (2009) on the presence of Wordsworth in Coetzee's work.

27 See also the similarly situated analysis by Herlinghaus, even though it rests on Benjamin's concept of the ecstatic when he posits in reference to this connection between global violence and Western modernity that "There is an immanent dimension to modern violence, as it comes objectified in a hidden sphere of the Western 'political unconscious', in whose perpetuation the humanist academic tradition plays its part” (2011: 106). 


\section{Spaces of violence, the return of history, and Apollo's defeat}

I argued at the outset of this essay that the novels by Coetzee and Bolaño are situated not just in the Global South, but also in the aftermath of the epochal watershed of 1989 that first brought forth the notion of the Global South. Both Disgrace and 2666, as well as Woes of the True Policeman, must be read as debates with certain optimistic historical-philosophical views that accompanied the end of historical constellations such as the Cold War or the apartheid regime in South Africa in the years before $2000^{28}$. The fact that these texts do not share these optimistic assumptions about the future, whether with a view to their respective periods or to other historical moments, becomes particularly clear in 2666, when the last part of the novel begins with the end of a specific historical event, namely the First World War, in a discussion between two disabled men: "According to the sergeant, everything was about to change. The war was coming to an end and a new era was about to begin. He answered, as he ate, that nothing would ever change. Not even the two of them had changed, and each had lost a leg” (Bolaño 2008: 638$)^{29}$. The post-Cold War era may also be unable to live up to its promise as a new phase of global prosperity and conviviality. The novel's message is that globalization, fundamentally determined by asymmetries, results in new forms of endemic violence and exploitation, as is seen in the devastations in Santa Teresa; these are the signs of an epoch that Óscar Amalfitano describes by saying, "we're plunged into the vulgar and savage fin de siècle" (Bolaño 2012: 36) ${ }^{30}$.

This pessimistic view of the world and history in Bolaño and Coetzee stems not least from the experiences that their "cultivated" protagonists confront in the precarious, marginal areas of the Global South. David Lurie leaves Cape Town and moves in with his daughter Lucy, who runs a small farm in the Eastern Cape region, while Amalfitano leaves Barcelona for Santa Teresa with his daughter Rosa, where he finds a new position at the university there and then meets the European philologists who are searching for "their" author, Benno von

28 The most prominent - and most trivialized and misunderstood - formulation of this optimism remains without a doubt Fukuyama (1992). See also the reading of Elizabeth Costello as a post-apartheid text in Bethlehem (2009) for more on the idea of a radically contingent perception of history in Coetzee.

29 "Según el sargento todo estaba a punto de cambiar. La guerra tocaba a su fin e iba a empezar una nueva época. Él le contestó, mientras comía, que nada iba a cambiar nunca. Ni siquiera ellos, que habían perdido cada uno una pierna, habían cambiado" (Bolaño 2004: 796). 30 "nosotros estamos acobados a un final de siglo vulgar y salvaje” (Bolaño 2011: 62). 
Archimboldi, in Santa Teresa. Both regions - northern Mexico and eastern South Africa - are constituted as regions that stand in glaring contrast to the urbane and "civilized" origins of the protagonists, and both texts refer explicitly to the long histories of violence in these regions. The Eastern Cape region is therefore "the most logical setting for a story concerned at its core with entitlement to the land in post-apartheid South Africa. It was in this part of the country that nine frontier Wars were fought between the British and the Xhosa people during the nineteenth century" (Cornwell 2003: 43). And while Jean-Claude Pelletier in 2666 has a view from his apartment into the urban landscape of Paris, on the Place de Breteuil and the UNESCO building as a metaphor of the cosmopolitan and Western idea of globalism and modern urban order (see Bolaño 2004: 31), the critics find themselves within a landscape of the Global South that is fundamentally defined by chaos and precariousness. As the policeman Lalo Cura describes: "Living in this desert [...] is like living at sea. The border between Sonora and Arizona is a chain of haunted islands. The cities and towns are boats. The desert is an endless sea. This is a good place for fish, especially deep-sea fish, not men" (Bolaño 2008: 559) ${ }^{31}$. Confronted with the violence and defenselessness of human life in these zones - as Lurie and his daughter experience when three young black men invade the farm, rape Lucy, beat Lurie, and try to light him on fire - the texts' protagonists articulate an understanding of history that is utterly antithetical to the idea of a teleological development that is optimistic about the future. Instead, the experience of violence in the present is interpreted in the context of a cyclical understanding of history as the return of a chain of violence-shaped events that stretches back far into the past; as Bolaño writes, "Everything will happen all over again” (Bolaño 2012: 63) 32 , or later on, “that history, which is a simple whore, has no decisive moments but is a proliferation of instants, brief interludes that vie with one another in monstrousness" (Bolaño 2012: 794) ${ }^{33}$. After the incident at the farm, Lurie also has to accept that the moderate optimism he once harbored can no longer hold. "The more things change the more they remain the same. History repeating itself, though in a more modest vein. Perhaps history learned a lesson" (1999: 62), Lurie thinks before the assault. Afterwards, contemplating the country's history of violence, he asks, "Why should I be allowed to live here

31 "Vivir en este desierto [...] es como vivir en el mar. La frontera entre Sonora y Arizona es un grupo de islas fantasmales o encantadas. Las ciudades y los pueblos son barcos. El desierto es un mar interminable. Éste es un buen sitio para los peces, sobre todo para los peces que viven en las fosas más profundas, no para los hombres” (2004: 698).

32 "Todo se va a volver a repetir" (2011: 97).

33 "[L]a historia, que es una puta sencilla, no tiene momentos determinantes sino que es una proliferación de instantes, de brevedades que compiten entre sí en monstruosidad” (2004: 993). 
without paying?” (1999: 158). This history simultaneously invokes an attempt to explain the perpetrators' behavior: "It was history speaking through them [...] A history of wrong. Think of it that way, if it helps. It may have seemed personal, but it wasn't. It came down from the ancestors” (1999: 156). The consequences of this experience of violence are expressed not only in the pessimism about history described here, but also in a fundamental doubt as to the possibility of confronting these realities of the Global South with the sublimating instruments of art, religion and language; as Lurie says in light of the assault,

He speaks Italian, he speaks French, but Italian and French will not save him here in darkest Africa. He is helpless, an Aunt Sally, a figure from a cartoon, a missionary in cassock and topi waiting with clasped hands and upcast eyes while the savages jaw away in their own lingo preparatory to plunging him into their boiling cauldron. Mission work: what has it left behind, that huge enterprise of upliftment? Nothing that he can see. (1999: 95)

The belief in the possibility of naming the horror, and thereby its at least potential banishment, is radically questioned against this background when Lurie admits, "More and more he is convinced that English is an unfit medium for the truth of South Africa" (1999: 117). In 2666, another reflection on the events in Santa Teresa runs thus:

In the nineteenth century [...] society tended to filter death through the fabric of words. Reading news stories from back then you might get the idea that there was hardly any crime, or that a single murder could throw a whole country into tumult. We didn't want death in the home, or in our dreams and fantasies, and yet it was a fact that terrible crimes were committed, mutilations, all kinds of rape, even serial killings. [...] Everything was passed through the filter of words, everything trimmed to fit our fear. [...] The Greeks, you might say, invented evil, the Greeks saw the evil inside us all, but testimonies or proofs of this evil no longer move us. They strike us as futile, senseless. (Bolaño 2008: 266) ) $^{34}$

This reference to Greek antiquity as a symbol for the possibility of an art that tries to grant form to a contingent experience of the world also surfaces in Elizabeth Costello when Elizabeth travels from Australia to an African university, where her

34 "En el siglo XIX [...] la sociedad acostumbraba a colar la muerte por el filtro de las palabras. Si uno lee las crónicas de esa época se diría que casi no había hechos delictivos o que un asesinato era capaz de conmocionar a todo un país. No queríamos tener a la muerte en casa, en nuestros sueños y fantasías, sin embargo es un hecho que se cometían crímenes terribles, descuartizamientos, violaciones de todo tipo, e incluso asesinatos en serie. [...] Todo pasaba por el filtro de las palabras, convenientemente adecuado a nuestro miedo. [...] Los griegos inventaron, por decirlo de alguna manera, el mal, vieron el mal que todos llevamos dentro, pero los testimonios o las pruebas de ese mal ya no nos conmueven, nos parecen fútiles, ininteligibles” (2004: 338). 
sister Blanche will receive an honorary doctorate. Elizabeth becomes involved in a discussion with her sister, who is actually a philologist, yet long ago turned away from an academic career. Instead, Blanche has spent her life as Sister Bridget in a mission that cares for people living with AIDS in a hospital in "Zululand", whereby this form of conversion forms the background for the debate about the possibility of positioning oneself, or engaging in ethical action, in view of the suffering in the world between art on one hand and religion on the other. In the following passage, Blanche justifies her devaluation of Greek ideals in favor of religion by pointing to art's alleged remoteness from reality as a form of solace in the face of human suffering: “Ordinary people don't want the Greeks. They don't want the realm of pure forms. [...] They want someone who suffers like them. Like them and for them" (Coetzee 2004: 144). This complex becomes the specific target in Blanche's explicit critique of the Apollonian, when she says, "You backed a loser, my dear. If you had picked a different Greek you might have stood a chance. Orpheus instead of Apollo. The ecstatic instead of the rational. [...] Someone who moves among the people, whom they can touch - can put their hand into the side of, feel the wound, smell the blood. But you didn't, and you lost. You went for the wrong Greeks, Elizabeth" (2004: 145).

Bolaño, in an essay entitled Literature + illness = illness and published in The Insufferable Gaucho, makes a similar remark when he notes, in a cultural diagnosis of the fall of the Apollonian: “There's no stopping Dionysus. He has infiltrated the churches and the NGOs, the governments and the royal families, the offices and the shantytowns. Dionysus is to blame for everything. Dionysus rules. [...] Where has that faggot Apollo got to? Apollo is ill, seriously ill” (Bolaño 2010: $129-130)^{35}$. It is in this context - the cataclysms of the world and of human life experienced by the novel's figures in precarious zones in the Global South, such as a hospital in Zululand or the workbenches of unbridled capitalism in northern Mexico - that Coetzee's Sister Bridget apodictically refers to the possibility, or impossibility, of art or the humanities to develop dimensions of salvation. What alone remains, according to the missionary, is the path to religion: "Well, it cannot be done [...] I am talking only about history, about the record of the humanist enterprise. It cannot be done. Extra ecclesiam nulla salvatio" (Coetzee 2004: 133). The fact that this radical yet simple option is not acceptable to the majority of the characters in Coetzee and Bolaño's novels raises the question of to

35 "Dioniso lo ha invadido todo. Está instalado en las iglesias y en las ONG, en el gobierno y en las casas reales, en las oficinas y en los barrios de chabolas. La culpa de todo la tiene Dioniso. El vencedor es Dioniso. [...] ¿Y dónde diablos está el maricón de Apolo? Apolo está enfermo, grave” (Bolaño 2003: 142-143). 
what degree this fundamental doubt in the capacity of literature and history, as symbolic systems of producing meaning out of human existence, are developed as possible alternatives beyond the flight into religion or an all-encompassing nihilism.

\section{The precarious state of the art: down-to-earth readings or a cosmopolitanism of fragility}

What defines the confrontations staged by Coetzee and Bolaño between traditional Western forms of order and the ascription of meaning - be it in the form of art, the humanities or history - with the specific and fragile realities of life in the Global South is therefore the recognition of the radical inadequacy of such ideas or their postulated cosmopolitan and universalistic effectiveness. Instead, these novels develop the specific and multiple material asymmetries in human living conditions in the context of contemporary globalization, as becomes clear in Disgrace and 2666 with regard to questions about the rule of law. So, for example, Óscar Amalfitano asks the U.S. journalist Oscar Fate to take his daughter Rosa to the USA because of the murders of women in Santa Teresa. Due to Rosa's Spanish citizenship (in contrast to the thousands of "illegal" immigrants from Mexico and Central America), this is possible and simple. Similarly, David Lurie tells his daughter Lucy, who has Dutch citizenship, to leave South Africa behind due to its lack of a functioning constitutional state and its endemic disorder and danger. Lucy, however, becomes a figure that takes a decided stand against this functional pattern of the cosmopolitan, of which Bolaño's European literature professors also make use when they quickly leave Mexico after the failure of their search for Archimboldi because of the threatening conditions there. "He is here, he won't disappear in a puff of smoke, he is a fact of life" (Coetzee 1999: 208), Lucy tells her father with regard to her neighbor Petrus, who offers Lucy protection (after the attack at the farm, which he is suspected of initiating) if she will marry him. "Petrus is not offering me a church wedding followed by a honeymoon on the Wild Coast. He is offering an alliance, a deal. I contribute the land, in return for which I am allowed to creep in under his wing. Otherwise, he wants to remind me, I am without protection, I am fair game’” (1999: 203), says Lucy by way of summary, laying bare in a painful way the problematic forms of negotiating coexistence beyond the comforts of cosmopolitan ideals. The inadequacy of thinking through these conflicts and precarious modes of existence by means of abstractions is made explicit when, in an argument between Lurie and his daughter about her decision to remain on the farm, he says, "Is it some form of private salvation you 
are trying to work out? Do you hope you can expiate the crimes of the past by suffering in the present?", to what Lucie answers, "No. You keep misreading me. Guilt and salvation are abstractions. I don't act in terms of abstractions. Until you make an effort to see that, I can't help you" (Coetzee 1999: 112). The confrontation enshrined in this dialog, between a radically contingent reality (that Lucy has long ago learned to accept through her experiences in the Eastern Cape) and the invalidity of abstract ideas (as she has internalized her father in his existence in the protected discursive and vital spaces of his life as a professor in Cape Town), leads to a successive undermining of any presumably stable forms of subjectivity or other categories of "knowledge about the world"; this is staged in the figure of Lurie as well as Elizabeth Costello and, in a slightly different way, in Bolaño. In this context, Philipp Dickinson has written of "proto-ethical moments" in Coetzee's novel, in the sense of "moments that resist the temporality of narrative while they instantaneously puncture Lurie's ego and disarm his conception of himself" (2013: 11) ${ }^{36}$. This becomes manifest in the text when Lurie slowly begins to give up the position of sovereignty that defines his existence in Cape Town in favor of a life in which his experiences of precariousness, and the inadequacy of how he comes to terms with the contingent, are expressed in modified patterns of action and reflection. For example, he begins working at an animal care facility run by his neighbor Bev, a woman he used to ridicule. The facility puts dogs to sleep and takes care of their proper disposal, which Lurie reflects upon as follows:

Curious that a man as selfish as he should be offering himself to the service of dead dogs. There must be other, more productive ways of giving oneself to the world, or to an idea of the world. [...] But there are other people to do these things - the animal welfare thing, the social rehabilitation thing, even the Byron thing. He saves the honour of corpses because there is no one else stupid enough to do it. That is what he is becoming: stupid, daft, wrongheaded. (Coetzee 1999: 146)

The idea formulated here by Lurie (and also discussed in Elizabeth Costello) of caritas (beyond the Christian context) as a form of relating with the world becomes readable here as a radical questioning of, or as an absence of, preconceived assumptions about the world and other people $\mathrm{e}^{37}$, with which Lurie previously

36 Elizabeth Costello also finds herself in a situation of uncertainty regarding her own positions, brought about by her experiences in Africa when she believes that a state of physical weakness belies a cause deeper than the mere stresses of her journey: "But is that the explanation? Is a two-day stomach upset enough to cause a faint?” (Coetzee 2004: 143).

37 Regarding the specific "non-human dimension" of this cosmopolitanism in Coetzee, see also Hallemeier 2013a: 123-152. 
overcame problematic experiences of difference, in the sense of an "unimaginative sympathy," as Sam Durrant has described with a view to Coetzee's work: "This failure [of sympathy] is the precondition for a new kind of ethical and literary relation, a relation grounded precisely in the acknowledgment of one's ignorance of the other, on the recognition of the other's fundamental alterity" (2006: 120-121). In this context, art and literature also no longer function as a medium for cultivating what Nussbaum calls the "sympathetic imagination”. Instead, they offer an opportunity to reflect on the unlearning of ostensibly secure cosmopolitan assumptions about coexistence and the connections between affect and art. This does not however dismiss the possibility of a cosmopolitan idea of conviviality; it merely questions, in its seamless applicability, the inescapable experience of difference, as Hallemeier underscores in her reading: "In its representation of the globalized 'new' South Africa, Coetzee's Disgrace imagines cosmopolitan community as that which is provincial in character and centered on the daily task of living with difference" (2013b: 109).

Both Coetzee and Bolaño's reflections, undertaken from the vantage point of the Global South regarding the conditions of global and local coexistence, become fully legible in the sense of a complex representation of "critical cosmopolitanism" (see Delanty 2012) ${ }^{38}$ or "cosmopolitanism from below" (see Kurusawa 2004). If the novels intentionally depict the confrontation of an allegedly civilized Western subject with an "other" - as was the case with the Pakistani taxi driver in 2666, or the neighbor Petrus in Disgrace - and present subjects who cannot be integrated smoothly into cosmopolitan discourse, it is no accident then that figures such as Lucy, or the numerous Mexican women in Bolaño, are female figures from whose perspective issues a problematization of the idea of the sovereign and primarily male subject; because, as Elizabeth Costello's sister Blanche says, "it is women who live closest to the ground" (Coetzee 2004: 145). This "proximity to the ground" becomes a subject of inquiry in the meta-reflections of these texts on the role of literature and the genre of the novel itself. The questioning of the significance of "narrative imagination" for the cultivation of empathetic cosmopolitan subjects goes hand-in-hand with a critique of the genre, paradoxically in the medium of the novel itself, which attempts, as Peter Vermeulen has shown, "[to] mobilize the conviction that the novel can no longer assume its authoritative cultural role" and that instead, it embarks upon a search for a possibility, "for the exploration of a weaker aesthetic mission, which is more attuned to forms of life that are no longer sovereign and centered, and to forms of affect that are not yet codified and controlled" (2015: 12). "I do not need to consult novels [...] to know

38 For further discussion of Delanty see also the contribution by César Domínguez in this book. 
what pettiness, what baseness, what cruelty human beings are capable of. That is where we start, all of us. We are fallen creatures" (Coetzee 2004: 128). Blanche emphasizes this scrutiny of the novel as a cosmopolitan and affective medium of contemplation. More than just the "end of the novel," as Vermeulen proclaims, it appears that Coetzee and Bolaño are concerned with a critique of the idea of the novel (or literature as such) as a form of transcendence that - in analogy to the fall of the humanities - can no longer be upheld in the contemporary world. In Disgrace, this phenomenon finds expression in the image of Lurie when he gives up his project - an opera about Byron's Italian journeys - in favor of a kind of corruption of this idea as a tinkering about on a toy banjo: "It is not the erotic that is calling to him after all, nor the elegiac, but the comic. He is in the opera neither as Teresa nor as Byron nor even as some blending of the two: he is held in the music itself, in the flat, tinny slap of the banjo strings, the voice that strains to soar away from the ludicrous instrument but is continually reined back, like a fish on a line" (Coetzee 1999: 184). This stance of self-ironic deconstruction also finds similar form in 2666 in the figure of a mystic named Florita Almada who appears on various television programs in Santa Teresa and is also presented as an insatiable reader of any type of books:

And she read every single one, and from each, without exception, she drew some lesson. [...] any kind of reading that providence placed within her reach, and she learned something each time, sometimes very little, but something was left behind, like a gold nugget in a trash heap, or, to refine the metaphor, said Florita, like a doll lost and found in a heap of somebody else's trash. Anyway, she wasn't an educated person, at least she didn't have what you might call a classical education. (Bolaño 2008: 430-431) ${ }^{39}$

Florita functions in the novel as a counter-figure to the European philologists as bearers of this "classic education", the value of which, as we have seen, becomes absurd as it is at no time capable of "reading" the complex connections of the surrounding world in a reasonable way. Florita, for her part, appears as a representative of a kind of "down-to-earth" reading who knows how to position her eclectic readings in practical life contexts while also making a series of "cosmopolitan" statements about the principle illegibility and complexity of the world,

39 "Y ella no dejó ni uno sin leer y de todos, sin excepción, extrajo alguna enseñanza. [...] cualquier tipo de lectura que la divina providencia pusiera al alcance de su mano, y de todos ellos aprendió algo, a veces muy poco, pero algo quedaba, como una pepita de oro en una montaña de basura, o para afinar la metáfora, decía Florita, como una muñeca perdida y reencontrada en una montaña de basura desconocida. En fin, ella no era una persona instruida, al menos no tenía lo que se dice una educación clásica” (Bolaño 2004: 539). 
which stands in opposition to the European cosmopolitans who remain convinced of their rationality. This serves Bolaño when he articulates his own ethical dimension of literature, writing: "To get a glimpse of other landscapes, which, though they might seem familiar, when you looked carefully were different [...]. Every hundred feet the world changes, said Florita Almada. The idea that some places are the same as others is a lie. The world is a kind of tremor" (Bolaño 2008: 430 $)^{40}$. While the European philologists are incapable of seeing through a world that is constantly changing, Florita Almada embodies a cosmopolitanism of fragility that stems from the brittleness of her existence in Santa Teresa and is, as it were, expanded in radically eclectic readings that find expression in the novel in Florita's discourse registers of the "popular", meaning ironic, and yet also "grounded", reality of life.

In Coetzee and Bolaño, literature functions as a medium shimmering between melancholy, comedy and madness, a phenomenon far removed from the idea of a rational decoding of a chaotic world, and of the novel as a medium of smooth cosmopolitan affect cultivation which, aware of its own shortcomings, perpetuates a belief in the possibility of a fragile power of transformation - at the price, of course, of being exposed to the danger of going insane during this endeavor of literary debate with the world ${ }^{41}$. This threat is expressed in Lurie's description of himself as a "mad old man who sits among the dogs singing to himself" (Coetzee 1999: 212) at the end of the novel, or in one of Bolaño's numerous monologues by Amalfitano, a character who strolls about at the margins of madness, when he makes the following remark about the essence of fiction:

Anyway, these ideas or feelings or ramblings had their satisfactions. They turned the pain of others into memories of one's own. They turned pain, which is natural, enduring, and eternally triumphant, into personal memory, which is human, brief, and eternally elusive.

40 "Para fijarse en otros paisajes, que aunque parecían el mismo, si uno los miraba bien, con los ojos bien abiertos, resultaban a la postre muy distintos de los paisajes de Villa Pesqueira. Cada cien metros el mundo cambia, decía Florita Almada. Eso de que hay lugares que son iguales a otros es mentira. El mundo es como un temblor” (Bolaño 2004: 538).

41 See also Coetzee's remarks on insanity in Erasmus in Coetzee (1996), as well as Stockhammer (2016) on the philo-a-logischen moments in Coetzee and Herlinghaus on the meaning of insanity in 2666, when he writes, "What crystallizes are sudden perceptions, images linked to aspects of possible distortions, or divinations of the improbable, but there are no coherent links whatsoever between a dramatic logic and (the motives or affects of) human behavior. The artistic tension arises between particular images and a caustic yet nonlinear narration. If madness is an issue, it is not backed by a respective set of behavioral or dramatic patterns, nor is it focalized in an introspective way. It is both a latent possibility in an insane world, and [...] a rare dispositif" (2013: 197). 
They turned a brutal story of injustice and abuse, an incoherent howl with no beginning or end, into a neatly structured story in which suicide was always held out as a possibility. They turned flight into freedom, even if freedom meant no more than the perpetuation of flight. They turned chaos into order, even if it was at the cost of what is commonly known as sanity. (Bolaño 2008: 189) ${ }^{42}$

\section{Works cited}

Appiah, Kwame Anthony (2001): “Cosmopolitan Reading”. In: Dharwadker, Vinay (ed.): Cosmopolitan Geographies: New Locations in Literature and Culture. London: Routledge, pp. 199-225.

Apter, Emily (2013): Against World Literature: On the Politics of Untranslatability. London: Verso.

Auerbach, Erich (1969): “Filology and 'Weltliteratur”. Transl. by Maire and Edward Said. In: The Centennial Review, 13, 1, pp. 1-17.

Bauman, Zygmunt (2004): Wasted Lives. Modernity and its Outcasts. Cambridge: Polity Press. Bethlehem, Louise (2009): “Elizabeth Costello as Post-Apartheid Text”. In: Boehmer, Elleke/ Iddiols, Katy/Eaglestone, Robert (eds.): J.M. Coetzee in Context and Theory. London: Continuum, pp. 20-35.

Birns, Nicholas (2015): “The part about the critics. The world reception of Roberto Bolaño". In: López-Calvo, Ignacio (ed.): Roberto Bolaño. Critical Insights. Ipswich: Salem Press, pp. 50-64.

Bloom, Paul (2016): Against Empathy. The Case for Rational Compassion. London: The Bodley Head.

Bolaño, Roberto (2012): Woes of the True Policeman. Transl. by Natasha Wimmer. New York: Farrar, Straus and Giroux.

- (2011): Los sinsabores del verdadero policía. Barcelona: Anagrama.

- (2010): The Insufferable Gaucho. Transl. by Chris Andrews. New York: New Directions.

- (2008): 2666. Transl. by Natasha Wimmer. New York: Farrar, Straus and Giroux.

- (2004): 2666. Barcelona: Anagrama.

- (2003): El gaucho insufrible. Barcelona: Anagrama.

Casanova, Pascale (1999): La République Mondiale des Lettres. Paris: Seuil.

Chakrabarty, Dipesh (2000): Provincializing Europe. Postcolonial thought and historical difference. Princeton: Princeton University Press.

42 "Estas ideas o estas sensaciones o estos desvaríos, por otra parte, tenían su lado satisfactorio. Convertía el dolor de los otros en la memoria de uno. Convertía el dolor, que es largo y natural y que siempre vence, en memoria particular, que es humana y breve y que siempre se escabulle. Convertía un relato bárbaro de injusticias y abusos, un ulular incoherente sin principio ni fin, en una historia bien estructurada en donde siempre cabía la posibilidad de suicidarse. Convertía la fuga en libertad, incluso si la libertad sólo servía para seguir huyendo. Convertía el caos en orden, aunque fuera al precio de lo que comúnmente se conoce como cordura" (Bolaño 2004: 243-244). 
Cheah, Pheng (2016): What is a World? On Postcolonial Literature as World Literature. London/ Durham: Duke University Press.

- (2006): Inhuman Conditions. On Cosmopolitanism and Human Rights. Cambridge: Harvard University Press.

Coetzee, John Maxwell (2004): Elizabeth Costello. Eight Lessons. London: Random House.

- (1999): Disgrace. New York: Penguin.

- (1996): "Erasmus. Rivalry and Madness". In: Giving offense. Essays on censorship. Chicago: University of Chicago, pp. 83-103.

Cornwell, Gareth (2003): "Disgraceland: History and the Humanities in Frontier Country". In: English in Africa, 30.2, pp. 43-68.

Damrosch, David (2003): What is World Literature? Princeton: Princeton University Press.

Delanty, Gerard (2012): “The Idea of Critical Cosmopolitanism”. In: Delanty, Gerard (ed.): Routledge Handbook of Cosmopolitan Studies. London: Routledge, pp. 38-46.

Dickinson, Philipp (2013): “Feeling, affect, exposure: Ethical (in)capacity, the sympathetic imagination, and J.M. Coetzee's Disgrace”. In: Mosaic, 46/4, pp. 1-19.

Durrant, Sam (2006): "J.M. Coetzee, Elizabeth Costello, and the Limits of the Sympathetic Imagination". In: Poyne, Jane (ed.): J.M. Coetzee and the Idea of the Public Intellectual. Athens: Ohio University Press, pp. 118-134.

Ette, Ottmar (2016): Writing-between-worlds: Transarea Studies and the Literatures-without-afixed-abode. Transl. by Vera M. Kutzinski. Berlin: de Gruyter.

Fukuyama, Francis (1992): The End of History and the Last Man. London: Hamish Hamilton.

Gumbrecht, Hans Ulrich (2004): Production of Presence. What Meaning Cannot Convey. Stanford: Stanford University Press.

- (2003): The Powers of Philology: Dynamics of Textual Scholarship. Urbana: University of Illinois Press.

Hallemeier, Katherine (2013a): J.M. Coetzee \& the Limits of Cosmopolitanism. New York: Palgrave Macmillan.

- (2013b): "Sympathy and Cosmopolitanism: Affective Limits in Cosmopolitan Reading". In: Culture, Theory and Critique, 54:1, pp. 88-101.

Helgesson, Stefan (2016): “How Writing Becomes (World) Literature: Singularity, The Universalizable, and the Implied Writer". In: Helgesson, Stefan/Vermeulen, Pieter (eds.): Institutions of World Literature: Writing, Translation, Markets. New York: Routledge, pp. 23-38.

Herlinghaus, Hermann (2013): Narcoepics. A Global Aesthetics of Sobriety. New York: Bloomsbury.

- (2011): "Placebo Intellectuals in the Wake of Cosmopolitanism: A 'Pharmacological' Approach to Roberto Bolaño's novel 2666”. In: The Global South, 5, 1, pp. 101-119.

Hoyos, Héctor (2015): Beyond Bolaño: The Global Latin American Novel. New York: Columbia University Press.

Keen, Suzanne (2007): Empathy and the Novel. New York: Oxford University Press.

Koppenfels, Martin von (2007): Immune Erzähler. Flaubert und die Affektpoetik des modernen Romans. Munich: Fink.

Kurasawa, Fuyuki (2004): “A Cosmopolitanism from Below: Alternative Globalization and the Creation of a Solidarity without Bounds". In: European Journal of Sociology, 45, 2, pp. 233-255.

Levander, Caroline/Mignolo, Walter (2011): “Introduction: The Global South and World Dis/ Order”. In: The Global South, 5, 1, pp. 1-11. 
Loy, Benjamin (2017): “La (in)soportable levedad de la tradición: hacia una lectura latinoamericana de la literatura mundial”. In: Inti: Revista de literatura hispánica, 85-86, pp. 36-52.

- (2017): “Nach den Elegien: Überlegungen zu einer kritischen Literaturwissenschaft". In: Drews, Julian et al. (ed.): Romanistik in Bewegung. Aufgaben und Ziele einer Philologie im Wandel. Berlin: Kadmos Kulturverlag, pp. 115-137.

Marling, William (2016): Gatekeepers: The Emergence of World Literature and the 1960s. New York: Oxford University Press.

McGann, Jerome (2008): “Pseudodoxia Academica”. In: New Literary History, 39, 3, pp. 645-656. Messling, Markus (2014): “2666: Die Moderne als Echolot der Globalisierung. Roberto Bolaño und das Erbe Baudelaires". In: Ette, Ottmar/Wirth, Uwe (eds.): Nach der Hybridität. Zukünfte der Kulturtheorie. Berlin: tranvía, pp. 199-215.

Moretti, Franco (2013): Graphs, Maps, Trees. London: Verso.

Nussbaum, Martha (2010): Not for profit. Why Democracy Needs the Humanities. Princeton: Princeton University Press.

- (1997): Cultivating humanity. A Classical Defense of Reform in Liberal Education. Cambridge: Harvard University Press.

Siskind, Mariano (2014): Cosmopolitan desires. Global Modernity and World Literature in Latin America. Evanston: Northwestern University Press.

Stockhammer, Robert (2016): Afrikanische Philologie. Berlin: Suhrkamp.

Vermeulen, Pieter (2015): Contemporary Literature and the End of the Novel. Creature, Affect, Form. New York: Palgrave Macmillan.

- (2009): "Wordsworth and the Recollection of South Africa". In: Boehmer, Elleke/Iddiols, Katy/Eaglestone, Robert (eds.): J.M. Coetzee in Context and Theory. London: Continuum, pp. 47-59. 